\title{
LANDASAN HISTORIS PENDIDIKAN KRISTEN DAN RELEVANSINYA DALAM PENDIDIKAN KRISTEN MASA KINI
}

Samuel Purdaryanto

Sekolah Tinggi Teologi Arastamar Bengkulu

samuelpurdaryanto@sttab.ac.id

\begin{abstract}
Abstrac
Education is part of the human formation process. This paper is entitled the historical foundation of Christian education. As part of the formation process, Christian education has a historical background from its inception to its development, so that it can become the foundation for Christian education today. Christian education is an effort to encourage people to have a real relationship with God. Christian education is not merely part of the school education curriculum. Christian education is a process of getting to know God's love through Jesus Christ that has occurred since the Old Testament times to the 20th century. This paper discusses the beginnings of Christian education in the Old Testament which began with the family and was closely related to Jewish education. Deuteronomy 6: 4-9 is a method or means used by the Jews to educate their children. After the exile the Jews also had different models and concepts of education. The journey of Christian education is also closely related to the educational legacy left by the Greeks and Romans. Even some methods or concepts of Greek education were adopted by church fathers to study and dig into the Word of God. In the New Testament, education is centered on Jesus Christ, because Jesus is the center of teaching himself. In His ministry on earth, Jesus also used methods in teaching, including methods of telling stories, parables, discussions, questions and answers and so on to convey His teachings to listeners. Christian education also continued to progress after the ascension of Christ to heaven where the apostles as a continuation of teaching discipled others to continue His teaching, so that Christian education continued into the 20th century. This study used a qualitative method with a descriptive approach to analysis and literature study. The results of this study provide an understanding of the historical foundation of Christian religious education which can be used as a reference for Christian educators today.
\end{abstract}

Key Words: Foundation, Historical, Christian Education, Teaching

\begin{abstract}
Abstrak
Pendidikan merupakan bagian dari proses pembentukan manusia. Tulisan ini berjudul landasan historis pendidikan Kristen. Sebagai bagian dari proses pembentukan, pendidikan Kristen memiliki latar belakang sejarah mulai dari dimulainya hingga perkembangannya, sehingga dapat menjadi landasan bagi pendidikan Kristen masa kini. Pendidikan Kristen merupakan upaya untuk mendorong orang-orang untuk mendapatkan hubungan yang sungguh-sungguh kepada Allah. Pendidikan Kristen bukanlah semata-mata bagian dari kurikulum pendidikan sekolah. Pendidikan Kristen merupakan proses untuk mengenal kasih Allah melalui Yesus Kristus yang sudah terjadi sejak zaman Perjanjian Lama hingga abad ke-20. Tulisan ini membahasa permulaan
\end{abstract}


pendidikan Kristen dalam Perjanjian Lama yang dimulai dari keluarga dan terkait erat dengan pendidikan Yahudi. Ulangan 6:4-9 merupakan metode atau cara yang digunakan orang Yahudi untuk mendidik anak-anak mereka. Sertelah pembuangan orang Yahudi juga telah memiliki model dan konsep pendidikan yang berbeda. Perjalan pendidikan Kristen juga berkaitan erat dengan warisan pendidikan yang ditinggal oleh Yunani maupun Romawi. Bahkan beberapa metode atau konsep pendidikan Yunani diadopsi oleh bapak-bapak gereja untuk mempelajari dan menggali Firman Allah. Dalam Perjanjian Baru, pendidikan berpusat kepada Yesus Kristus, karena memang Yesus pusat pengajaran itu sendiri. Dalam pelayanan-Nya di dunia, Yesus pun menggunakan metode dalam mengajar, diantara metode bercerita, perumpamaan, diskusi, Tanya jawab dan sebagainya untuk menyampaikan pengajaranNya kepada pendengar. Pendidikan Kristen juga terus maju paska kenaikan Kristus ke surga dimana para rasul sebagai penerus pengajaran yang memuridkan orang lain untuk melanjutkan pengajaranNya, sehingga pendidikasn Kristen terus berkelanjutan hingga pada abad ke-20. Penelitian ini menggunakan metode kualitatif dengan pendekatan deskriptif analisis dan studi pustaka. Hasil penelitian ini memberikan pemahaman landasan historis pendidikan agama Kristen yang dapat dijadikan acuan bagi pendidika Kristen masa kini.

Kata Kunci: Landasan, Historis, Pendidikan Kristen, Pengajaran

\section{PENDAHULUAN}

Menurut Kevin E. Lawson sebagaimana tertulis dalam Michael Anthony, pendidikan Kristen dapat dilihat sebagai upaya mendorong orang-orang untuk mendapatkan hubungan yang sungguh-sungguh dengan Allah. ${ }^{1}$ Namun demikian, dewasa ini beberapa orang gagal memahami pendidikan Kristen sebagai cara untuk mendapatkan hubungan dengan Allah. Hal ini disebabkan kesalahan dalam memahami Pendidikan Agama Kristen (PAK) yang hanya dipahami sebatas dimensi ilmu saja. Hamambira menuliskan bahwa pendidikan agama Kristen tidak bisa dipahami sebatas dimensi ilmu saja, namun juga memiliki dimensi religious, dimana orang percaya dapat bertumbuh melalui pembelajaran Pendidikan Kristen. ${ }^{2}$

Dalam pandangan penulis, barangkali kegagalan dalam memahami tujuan dan sifat pendidikan Kristen karena tidak melihat pada sejarah pendidikan Kristen. Terkait akan hal ini Pazmino menulis, dalam menghadapi tantangan pelayanan pendidikan, orang Kristen bisa belajar dari masa lalu untuk mendapatkan pengetahuan tentang apa yang harus dilakukan dimasa kini dan masa depan. ${ }^{3}$ Penulis setuju dengan apa yang disampaikan oleh Pazmino, bahwasannya melihat kepada sejarah atau masa lalu pendidikan Kristen itu penting, agar dapat digunakan untuk memahami pendidikan Kristen masa kini dan masa yang akan datang. Sehingga, tujuan dari pendidikan Kristen untuk mendorong orang-orang berhubungan dengan Allah dapat dicapai. Sesungguhnya pendidikan Kristen merupakan aspek penting dalam membangun jemaat dalam sebuah gereja untuk pertumbuhan iman Kristen.

Ketika tujuan pencapaian pertumbuhan iman dengan mendorong orang membangun hubungan dengan Allah tidak tercapai, perlu adanya pendekatan. Berbagai

\footnotetext{
${ }^{1}$ Anthony Michael J(Ed), Fondasi Pendidikan Abad 21 (Malang: Gandum Mas, 2017).

2 Domianus Lodu Hamambira, "Meletakan Kedudukan PAK Secara Tepat Dan Tepat Sasaran Seperti Ajaran Yesus," Integritas: Jurnal Teologi 1, no. 1 (June 27, 2019): 74-92.

3 Robert W Pazmino, Fondasi Pendidikan Kristen (Bandung: STT Bandung Dan BPK Gunung Mulia, 2012). 175
} 
pendekatan untuk mencapai tujuan pendidikan Kristen telah dilakukan sepanjang masa. Tulisan ini penulis memberikan deskripsi tantang berbagai cara formal dan informal yang dilakukan umat Allah untuk mendorong orang lain bertumbuh mengenal Allah. Ulasan kesejarahan perlu disampaikan agar memberikan pemahaman mengenai apa yang telah dilakukan oleh umat Allah dimasa lampau untuk mendorong umat Allah lainnya membangun hubungan dengan Allah dan bertumbuh. Melalui deskripsi dapat melihat bagaimana sejarah pendidikan Kristen mencatat peristiwa-peristiwa dimana komunitas orang percaya membangun hubungan dengan Allah melalui pendidikan agama Kristen. Sehingga cara-cara yang dipakai dimasa lampau dapat diterapkan bahkan dimodifikasi sebagai upaya untuk mendorong pertumbuhan iman Kristen pada masa kini.

\section{METODE}

Dalam penulisan karya tulis diperlukan suatu metode. Metode merupakan suatu cara yang telah diatur untuk berpikir baik -baik untuk mencapai suatu maksud dalam ilmu pengetahuan. Penelitian ini menggunakan metode kualitatif. Menurut Borg dan Gall sebagaimana dikutip oleh Wijaya, metode kualitatif merupakan metode artistic dikarenakan penelitiannya bersifat interpretasi terhadap data yang ditemukan, bersifat literature sebagai objek yang dikaji. ${ }^{4}$ Metode kualitatif memiliki pendekatan yang beragam dalam penelitian akademis. ${ }^{5}$ Adapun pendekatan yang digunakan adalah deskriptif analisis. Prosedur penelitiannya adalah; penulis meneliti pandangan dan teoriteori dengan menggunakan kajian pustaka atau library research. Selanjutnya menganalisa pandangan dan teori-teori tersebut, kemudian mendeskripsikannya.

\section{HASIL DAN PEMBAHASAN}

Bagian awal tulisan ini telah menyinggung kegagalan dalam memahami pendidikan Kristen sehingga tujuan dari pendidikan Kristen itu sendiri tidak tercapai. Oleh karena itu, mengulas sejarah perkembangan pendidikan Kristen perlu menjadi kajian sebagai landasan atau fondasi pendidikan Kristen, agar dapat melihat apakah relevan sejarah pendidikan Kristen tersebut, dijadikan landasan pada masa kini. Meskipun sejarah tidak bisa dijadikan sarana pencarian solusi cepat dan mudah bagi masalah masa kini dan masa depan, namun dari penyelidikan sejarah dimungkinkan untuk membedakan ketertarikan, kepedulian, masalah dan isu-isu yang secara konsisten ada dan terus berulang di dalam bidang pendidikan. ${ }^{6}$ Berikut ini adalah sejarah pendidikan Kristen dan perkembembangannya dari masa ke masa.

\section{Pendidikan Dalam Perjanjian Lama}

Dalam membahas pendidikan masa Perjanjian Lama, tidak bisa dipisahkan dari pendidikan Yahudi. Oleh karena itu, pembahasan bagian ini akan berkaitan erat dengan pendidikan agama Yahudi. Menurut Boehlke, "sejarah perkembangan pendidikan agama Yahudi dapat dibagi dalam dua zaman yang pokok, yang pertama itu mulai saat terbentuknya bangsa Israel dan berjalan terus sampai tahun 586 SM, dan kedua, mulai

\footnotetext{
${ }^{4}$ Hengki Wijaya, "Metode-Metode Penelitian Dalam Penulisan Jurnal Ilmiah Elektronik," In Strategi Menulis Jurnal Untuk Ilmu Teologi (Semarang: Golden Gate Publishing, 2020), 23-42.

${ }^{5}$ John W. Creswell, Research Design, 4th ed. (Yogyakarta: Pustaka Pelajar, 2019). 245

${ }^{6}$ Pazmino, Fondasi Pendidikan Kristen. 178-179
} 
dengan pembuangan dan diteruskan sampai permulaan gerakan Kristen". Dalam sejarah Israel sebagai bangsa, keluarga merupakan lembaga pendidikan utama dalam masyarakat. Anak-anak belajar secara informal dengan melihat keteladanan orang tua mereka. Selain itu juga, para ayah juga berperan mengajar anak-anak tentang hukum Allah dan kekayaan iman Yahudi kepada generasi baru (anak-anak), pandangan ini diperkuat oleh Salomo dalam amsal 22:6 "Didiklah anak muda menurut jalan yang patut baginya, maka pada masa tuanyapun ia tidak akan menyimpang dari jalan itu".

Tujuan pendidikan dalam Perjanjian Lama adalah membawa orang kepada kekudusan dan transformasi. ${ }^{8}$ Ulangan 6:4-9 yang sering disebut juga sebagai Shema atau pengakuan iman Yahudi menyajikan saran-saran proses pendidikan, dan juga dapat disebut sebagai pola mendidik anak-anak. Pola pengajaran yang diterapkan oleh Musa kepada bangsa Israel; pertama, orang tua harus mengasihi Tuhan dengan segenap hati mereka dan menyimpan hukum-hukum-Nya di dalam hati mereka (Ul 6;5-6), kemudian mengajarkan kepada anak-anaknya dalam aktivitas sehari-hari. Kitab ulangan memperingatkan bangsa Israel untuk mengingatkan anak-anak mereka mengenai pekerjaan ajaib Allah yang memimpin bangsa itu dimasa lalu, supaya anak ini melayani Allah dengan kerelaan hati. ${ }^{9}$ Pendidikan Yahudi pada awal-awal belum ada sekolah formal untuk anak-anak belajar, jadi yang menjadi konteks utama dari pendidikan ini adalah rumah, dan orang tua bertanggung jawab untuk mengajar. Metodologi yang digunakan bergantung pada komunikasi oral yang disertai alat bantu menghafal, termasuk puisi, permainan kata-kata dan teka teki. ${ }^{10}$ Kegiatan belajar dilakukan dengan waktu yang telah ditentukan, atau juga spontan.

Sesudah pembuangan ke Babel hidup keagamaan orang-orang Yahudi di Palestina dan diluar Palestina berpusat dalam rumah-rumah ibadah. Pusat pendidikan tidak lagi berpusat pada rumah atau keluarga saja, tetapi di rumah ibadah. Rumahrumah ibadah dimaksudkan sebagai rumah-rumah pengajaran bagi rakyat. Maksudnya rumah-rumah pengajaran, dimana rakyat diajar (dididik) dalam pengetahuan tentang Thorah. Pengajaran ini terdiri dari pengakuan iman (Shema), doa utama (Shemore Esre) yang harus didoakan tiga kali sehari oleh orang-orang Yahudi. ${ }^{11}$ Pada zaman ini, yang berhak mengajar orang Yahudi secara mendalam untuk hidup sebagai umat pilihan Allah adalah para nabi, kaum bijaksana dan kaum penyair. Anak laki-laki berhak menerima pengajaran tentang Taurat, nubuat dan tulisan-tulisan lainnya (kitab Mazmur, Talmud dan haggadah). Tetapi anak perempuan dididik tentang berbagai keterampilan seperti menenun. ${ }^{12}$ Pendidikan bangsa Yahudi pasca pembuangan mengalami perubahan, teologi mereka yang dahulu cukup teguh perlu dipikirkan ulang lagi khususnya pandangan tentang sebagai umat terpilih dan arti dari pandangan itu sendiri. ${ }^{13}$

\footnotetext{
${ }^{7}$ Robert R Boehlke, Sejarah Perkembangan Pikiran \& Praktek Pendidikan Agama Kristen (Jakarta: BPK Gunung Mulia, 2018). 19

${ }^{8}$ Pazmino, Fondasi Pendidikan Kristen. 186

${ }^{9}$ Louis Berkhof and Cornelis Van Till, Foundation of Christian Education (Surabaya: Momentum, 2004). 45

${ }^{10}$ Pazmino, Fondasi Pendidikan Kristen. 187

${ }^{11}$ JL.CH Abineno, Sekitar Katekese Gerejawi (Jakarta: BPK Gunung Mulia, 2005). 72

${ }^{12}$ Boehlke, Sejarah Perkembangan Pikiran \& Praktek Pendidikan Agama Kristen. 44

${ }^{13}$ Riniwati Riniwati, Magdalena Magdalena, and Aprianty Susanty, "Implikasi Praktik Pendidikan Orang Yahudi Pasca Pembuangan Ke Babel Bagi Pendidikan Kristen Masa Kini," The Messengers: Jurnal Teologi Dan Pendidikan Kristen 1, no. 1 (2020): 25-38.
} 


\section{Pendidikan Warisan Yunani-Romawi}

Yunani dikenal sebagai bangsa yang sangat maju pada masa itu, menguasai hampir seluruh daratan eropa dan Asia kecil. Dalam bidang kebudayaan Yunani juga sudah menjadi bangsa yang maju. Yunani juga dikenal memiliki pendidikan yang baik, banyak pemikir dan pembelajar yang berasal dari Yunani. Filsuf Aristoteles, Socrates dan Plato adalah filsuf besar yang berasal dari Yunani. Filsafat dan logika merupakan bagian penting dalam pendidikan Yunani. Research dengan logika merupakan ciri dari pendidikan Yunani. Metode bertanya dengan menggunakan rasio dan terus mencari merupakan aktivitas yang sering terjadi dalam pendidikan Yunani. Karena mengedepankan logika atau rasio dalam studi, seringkali sulit diterima dalam pendidikan Kristen, karena cenderung tanpa dasar dan menolak Alkitab. Namun demikian, para filsuf Yunani tersebut tetap memiliki pemikiran dibidang pendidikan. Sebut saja Plato, pikirannya tentang pendidikan dimuat dalam bukunya yang berjudul republic. ${ }^{14}$ Terkait tentang pendidikan dalam pandangan Plato Boehlke menulis, bahwa menurut Plato ruang lingkup pendidikan terdapat tiga bagian pokok, yaitu perkembangan emosi, tubuh dan akal. ${ }^{15}$

Tidak bisa dipungkiri bahwa pendidikan Kristen dipengaruhi oleh pendidikan Yahudi. Hal ini dapat dilihat dari dasar iman Kristen yang memasukan Perjanjian Lama sebagai dasar pengajaran yang menyatakan perbuatan hebat Allah dimasa lampau ditengah-tengah umat Israel. Akan tetapi, menurut Boehlke, dunia mereka tidak terbatas pada hal-hal yang bersifat Yahudi saja, namun orang Kristen pertama dibesarkan dalam negeri yang dipengaruhi kebudayaan Yunani lebih dua ratus tahun lamanya. ${ }^{16}$ Sudah pasti gaya berpikir Yunani, budaya dan bahasa Yunani sudah menjadi bagian dari hidup mereka. Oleh karenanya, pendidikan Kristen juga dipengaruhi oleh pemikiran Yunani, dan mungkin saja Romawi karena Romawi juga pernah berkuasa diawal gereja berdiri.

Cara berpikir barat sangat dipengaruhi oleh cara berpikir orang Yunani, sejalan dengan itu pola pikir dan praktik pendidikan sangat dipengaruhi oleh warisan intelektual Yunani yang unik. ${ }^{17}$ Sokrates dan Plato adalah para pemikir intelektual Yunani yang cara berpikir dan pemikirannya mempengaruhi pendidikan. Meskipun, menurut para ahli tidak banyak hal yang bisa diketahui dari Sokrates, namun dari muridnya yang bernama Plato terlihat warisan dunia intelektual tentang Sokrates. Tentang kebaikan, Sokrates mengatakan bahwa pengetahuan itu sendiri adalah kebaikan yang sangat berharga, untuk dapat benar-benar mengetahui apa yang baik itu adalah melarang orang untuk melakukan kejahatan. Sokrates menekankan pentingnya kehidupan moral, tetapi bukan dalam pengertian Tuhan orang Yahudi. ${ }^{18}$ Dalam pemikiran Socrates, akal manusia berpengaruh dalam pembentukan moral manusia.

Selanjutnya ada Plato, seorang intelektual Yunani lainnya. Plato merupakan murid dari Sokrates, Pazmino mengatakan bahwa Plato berpengaruh lebih besar pada kehidupan komunitas Kristen. ${ }^{19}$ Agustinus adalah pemikir Kristen yang tertarik dengan pemikiran Plato, dan kemudian mensitesiskan dengan iman Kristen. Plato mendirikan sekolahnya yang disebut akademi, yang sampai sekarang masih diikuti. Konsep Yunani

\footnotetext{
${ }^{14}$ Boehlke, Sejarah Perkembangan Pikiran \& Praktek Pendidikan Agama Kristen. 6

${ }^{15}$ Ibid. 7

16 Ibid. 1

${ }^{17}$ Pazmino, Fondasi Pendidikan Kristen. 188

${ }^{18}$ Ibid.

${ }^{19}$ Ibid. 188
} 
yang cukup signifikan adalah paideia. Paideia melambangkan konsesus budaya mengenai hal yang membentuk kesempurnaan manusia. ${ }^{20}$ Penggunaan istilah paideia yang alkitabiah merujuk kepada pemeliharaan, disiplin dan pembentukan karakter, yang mengimplikasikan bahwa manusia itu secara murni berkom itmen dan secara vital terhubung satu sama lain dalam sebuah komunitas. Sehingga manusia harus berkomunitas dengan sesamanya mengasihi dan membangun sesama.

Selain Yunani, Romawi juga pernah menjadi penguasa dibelahan Eropa dan Asia kecil dan cukup lama. Oleh karenanya ketika membahas warisan pendidikan Yunani, tidak bisa mengabaikan pendidikan era Romawi. Dalam dunia pendidikan bangsa Romawi tidak memiliki hokum yang mengharuskan warganya memperoleh pendidikan tingkat minimum. Anak-anak Romawi secara umum dididik di rumah oleh orang tuanya, atau jika itu keluarga bangsawan mereka akan memanggil tutor. ${ }^{21}$ Pendidikan Romawi juga sangat dipengaruhi oleh pendidikan Yunani, guru-guru Romawi umumnya merupakan budak Yunani, sehingga memberikan pengaruh ketika guru tersebut mengajar orang romawi.

Sesungguhnya, pendidikan Romawi sudah memiliki konsep sejak kanak-kanak. Abad ke-4 SM telah terbentuk Ludi atau setara dengan kelompok bermain yang merupakan akibat dari pembentukkan republic Romawi. ${ }^{22}$ Dalam masa republic pendidikan di Romawi mendapat peran penting bahkan sampai pada kekaisaran Romawi. Dalam model pendidikan Romawi, sudah memiliki konsep misalnya saja pendidikan dasar fisik dan moral berada dalam pengawasan ketat orang tua. Salah satu pemikir atau tokoh pendidikan Romawi yang cukup berpengaruh adalah Quintilanes (35-95 M). Boehlke mengatakan bahwa Quintilanes merupakan guru Romawi pertama yang diangkat sebagai guru Rhetorika (seni bicara didepan umum) yang dibayar oleh Negara. ${ }^{23}$ Quintilanes sering disebut juga sebagai professor dibidang pidato. Quintilanes memiliki pergumulan masalah mencari pendidikan yang melatih atau melengkapi orang-orang sehingga mampu melaksanakan tugas yang diperlukan masyarakat dengan lebih sempurna. ${ }^{24}$ Ia memiliki sumbangan yang cukup besar dalam perkembangan pendidikan Romawi terkait dengan pendidikan anak, Ia memperlakukan setiap anak didik sebagai seorang pribadi perlu dihormati. Hal ini berpengaruh dengan pendidikan di eropa hingga saat ini dalam mendidik anak-anak.

A. Pendidikan Dalam Perjanjian Baru

Contoh bentuk pengajaran dalam perjanjian baru yang dapat kita teladani adalah kisah tentang pengajaran yang diterima oleh Tuhan Yesus pada saat Dia menjadi manusia. Pada abad pertama Masehi pengajaran iman Kristen berkisar pada diri Yesus Kristus sendiri. Yesus sebagai buah dari pendidikan agama Yahudi dalam arti bahwa hubunganNya yang khusus dengan BapaNya tidak membebaskanNya dari keperluan belajar sama seperti anak laki-laki Yahudi lainnya. ${ }^{25}$ Demikian juga dengan para murid Yesus juga mengikuti pola penyembahan dan pembelajaran orang Yahudi. Selain itu, beberapa kitab Perjanjian Baru menunjukan metode berbeda yang mencerminkan

\footnotetext{
${ }^{20}$ Ibid. 190

${ }^{21} \mathrm{https}$ ///www.amazine.co/22032/sekolah-romawi-sistem-pendidikan-pada-jaman-romawi-kuno/diakses 15 April 2021

${ }^{22}$ Ibid

${ }^{23}$ Boehlke, Sejarah Perkembangan Pikiran \& Praktek Pendidikan Agama Kristen. 13

${ }^{24}$ Ibid. 14

${ }^{25}$ Ibid. 57
} 
budaya Yahudi kuno. Kendatipun demikian, kombinasi idealism pendidikan Perjanjian Lama dan warisan Yunani kuno terlihat dalam pendidikan Perjanjian Baru.

Dalam Perjanjian Baru, Yesus dan pengajaran-Nya menjadi pusat pendidikan Kristen. Meskipun ada ahli taurat dan orang farisi, pengajaran Yesus itu unik dalam banyak hal. Terkait akan hal ini, menurut Lawson dalam Michael Anthony,

Pengajaran Yesus unik menarik, Pertama; Yesus mengajar sebagai orang yang memiliki otoritas, ketika Ia mengajar kitab suci, Ia memberikan penafsiran-Nya sendiri, bukan penafsiran yang dihafal dari Mishnah atau diberikan oleh otoritas tradisi(Mrk. 1:22). Kedua, Ia mengajar banyak orang dimana para guru pada zaman-Nya tidak memberikan perhatian kepada para wanita, orang bukan Yahudi, dan anak-anak. Ketiga, Yesus mengajar kemana Ia pergi, di siangog, rumah-rumah, di tepi laut, perbukitan dimanapun orang berkumpul. Keempat, Ia mengajar dengan metode yang beragam. Pelajaran dengan benda, perumpamaan, percakapan, dan kalimat tertentu untuk menolong. ${ }^{26}$ Dan yang lebih penting di atas semuanya itu, Yesus menghidupi pengajaran-Nya dengan memberi teladan kepada kelompok yang diajar-Nya. Pendidikan dan pengajaran Yesus sangat berbeda dengan rabi- rabi Yahudi pada waktu dan juga para ahli taurat lainnya. Keteladanan dalam mengasihi Allah dan sesama membuat apa yang diajarkan menjadi lebih hidup dan mengubah.

Selain pengajaran Yesus yang unik dan metode pengajaran-Nya, Perjanjian Baru juga mencatat beberapa tokoh Perjanjian Baru yang belajar iman Kristen melalui keluarga. Misalnya Timotius yang belajar dari Louis neneknya dan juga Eunike ibunya (1 Tim. 1:5; 3:15). Lalu ada juga sida-sida Etiophia yang belajar dari Filipus(Kisah rasul 8:36-40). Pendidikan secara bertahap menekankan pada cara hidup umat pilihan Allah yang berbeda. ${ }^{27}$

Amanat agung (Mat 28:20) memberikan mandat untuk mengajar dan mentaati semua yang Yesus perintahkan. Mendidik dan mengajar merupakan bagian penting dalam pertumbuhan iman Kristen untuk mengenai Allah. Kitab Kisah Para Rasul menunjukan bagaimana murid Kristus mulai melaksanakan Amanat Agung (KPR 2:42; $5: 42 ; 6: 2){ }^{28}$ Setelah kenaikan Yesus ke Sorga dan Roh Kudus dicurahkan para murid segera mengajar, berkhotbah menyampai berita kematian dan kebangkitan Yesus, dan mengajak orang lain untuk percaya kepada Yesus. Perjanjian Baru sesungguhnya telah memiliki konsep pendidikan Kristen, dan Yesus merupakan pusat pengajarn Kristen sekaligus teladan dalam mengajar.

B. Pendidikan Zaman Gereja Mula-Mula

Pada zaman gereja mula-mula terjadi transisi kepemimpinan dan pengajaran dalam gereja. Dimana kepemimpinan dan pengajaran para Rasul akan diteruskan kepada generasi-generasi berikutnya untuk melayani para murid dimasa depan. Warisan Kristen yang benar terus disampaikan ditengah masyarakat yang jahat, dan gereja memilih untuk kontra terhadap budaya demi menjaga kemurniaan iman Kristen. ${ }^{29}$ Pendidikan mulai diupayakan dalam bentuk baru, dan apa yang semula menjadi gerakan bangsa Yahudi, menjadi gerakan bangsa non-Yahudi.

Gereja menghadapi tantangan dengan munculnya kekacauan yang disebabkan oleh berbagai pengajaran doktrin. Pemimpin gereja yang juga seorang apologis mengajar tentang iman Kristen. Menurut Jame E. Reed sebagaimana dikutip oleh

\footnotetext{
${ }^{26}$ Michael J, Fondasi Pendidikan Abad 21. 18-19

${ }^{27}$ Pazmino, Fondasi Pendidikan Kristen. 193

${ }^{28}$ Michael J, Fondasi Pendidikan Abad 21. 19

${ }^{29}$ Pazmino, Fondasi Pendidikan Kristen. 198
} 
Lawson dalam karya Anthony, seorang pemimpin jemaat mengadakan pengajaran atau cathedra di gereja-gereja utama di daerah tersebut, dan bertanggung jawab untuk mendidik orang-orang yang baru bertobat dan mengajar serta menilik para pemimpin yang lain. ${ }^{30}$ Sekolah Catechumenal merupakan sekolah yang dikembangkan mempersiapkan petobat baru utuk baptisan. Lamanya dua sampai tiga tahun, para calon mendengarkan khotbah-khotbah, serta diajar menafsirkan doktrin Alkitab dan doa. Selanjutnya pada akhir abad kedua, sekolah ini mulai memperluas kurikulum dengan memasukan teologia yang lebih tinggi serta filsafat, logika dan retorika untuk dipersiapkan melawan pengajar-pengajar sesat. Secara umum, lembaga-lembaga pendidikan Kristen mendapat dukungan pemerintah bahkan, setelah abad ke empat, banyak pemimpin gereja mulai mempertimbangankan jenis pendidikan yang harus diterima oleh orang Kristen dan bagaimana menyampaikannya. ${ }^{31}$ Bilo menambahkan bahwa filsafat dan teologi juga perlu dikembangkan untuk menemukan kebenaran Alkitab. ${ }^{32}$

C. Pendidikan Kristen Abad Pertengahan

Memasuki abad ke empat, sejarah melaporkan bahwa kekristenan tidak lagi berada dalam tekanan penganiayaan. Constatine adalah kaisar Romawi yang memulainya dan juga menjadikan Kristen sebagai agama Negara. ${ }^{33}$ Setelah abad ke empat, kekaisaran Romawi berakhir, kerajaan dan Negara muncul dan jatuh gereja menjadi kekuatan dominan dalam budaya barat. Peran pendidikan kristenpun berubah, gereja tidak lagi membutuhkan persiapan intesif bagi mereka yang mau bergabung menjadi anggota. ${ }^{34}$ Pemimpin gereja harus berpikir memikirkan cara yang baru untuk membina dan memelihara sejumlah besar orang yang menjadi anggota gereja, agar dapat memahami iman lebih mendalam.

Lawson dalm Michael Anthony menulis, bahwa masyarakat abad pertengahan terbagi dalam tiga "kelompok" para imam (pendeta, biarawan), yang berdoa untuk semua orang, kaum bangsawan(ningrat, ksatria) yang memerintah dan melindungi mereka, dan orang umum(pedagang, budak dan pekerja) yang memberi mereka makan. ${ }^{35}$ Pendidikan formal diupayakan untuk memenuhi kebutuhan kelompokkelompok tersebut. Menurut Marvin J. Taylor sebagaimana dikutip oleh Pazmino, dominasi gereja yang meningkat berdampak pada pendidikan. ${ }^{36}$ Gereja memiliki peran untuk mendidik orang-orang tersebut. Dalam sekolah-sekolah paroki, yang merupakan turunan sekolah catechumenal, pengajaran dasar diberikan kepada orang awam. Adapun pelajaran dasar tersebut meliputi sepuluh perintah Allah, tujuh dosa mematikan, tujuh karakter cardinal, kredo para rasul dan doa Bapa kami. ${ }^{37}$

Pada abad ini, biara mulai mendirikan sekolah-sekolah dimana orang-orang yang ingin bergabung dan masyarakat yang berasal dari sekitarnya diizinkan datang belajar membaca, aritmatika, doa dan kitab suci. ${ }^{38}$ Selain itu, pada abad ke sebelas perkembangan pendidikkan juga semakin maju, dimana sekolah-sekolah katedral telah

\footnotetext{
${ }^{30}$ Michael J, Fondasi Pendidikan Abad 21. 22

${ }^{31}$ Ibid. 21

${ }^{32}$ Dyulius Thomas Bilo, "Korelasi Landasan Teologis Dan Filosofis Dalam Pengembangan Prinsip Dan Praksis Pendidikan Agama Kristen,” Phronesis Jurnal Teologi dan Misi 3, no. 1 (August 12, 2020): 1-22.

${ }^{33}$ Th. Van den End, Harta Dalam Bejana (Jakarta: BPK Gunung Mulia, 2010).

${ }^{34}$ Pazmino, Fondasi Pendidikan Kristen. 198

${ }^{35}$ Michael J, Fondasi Pendidikan Abad 21. 22

${ }^{36}$ Pazmino, Fondasi Pendidikan Kristen. 192

${ }^{37}$ Michael J, Fondasi Pendidikan Abad 21. 23

${ }^{38}$ Ibid.
} 
berkembang menjadi universitas. Pada tahap ini, penggunaan logika Aristoteles digunakan untuk mendukung dan memahami doktrin gereja, Anselm dan Thomas Aquinas merupakan pengajar yang menggunakan upaya-upaya ini.

D. Pendidikan Kristen Abad Reformasi dan Pencerahan

Pendidikan Kristen terus mengalami berkembangan dari tahun ke tahun bahkan sampai era reformasi gereja. Sebelum lebih jauh membahas pendidikan Kristen di zaman reformasi gereja, sejenak melihat bagaimana pendidikan Kristen menjelang reformasi. Budiyana dalam tulisannya menyoroti seorang tokoh yang bernama Disiderius Erasmus yang lahir 27 Oktober 1446 di Rotterdam. Tentang pendidikan Erasmus berpandangan; pengalaman pendidikan formal entah yang berlangsung di sekolah negeri/swasta atau pendidikan dikalangan jemaat hendaknya mengembangkan karunia apa saja dalam setiap pelajar dan menghargai kebebasan berpikir. ${ }^{39}$

Era reformasi gereja didahului dengan renaisans atau masa pencerahan dimana terjadi kebangunan intelektual, rasa nasionalisme yang tinggi dan tidak ingin lagi tunduk lagi pada arahan pemimpin jarak jauh termasuk Paus. Pada masa ini filsafat juga telah mengalami perkembangan. Filsafat telah digunakan dan diintegrasikan dalam berteologi untuk membangun argument-argumen dalam mempertahankan iman Kristen ataupun membongkar kesalahan. ${ }^{40}$ Posisi istimewa gereja dimasyarakat yang telah berlangsung lama mendapat tantangan dan berakibat kepada reformasi gereja dan pembaharuan pendidikan Kristen. Para reformator tidak hanya memperbaharui gereja mereka juga memberikan sumbangan bagi pendidikan agama Kristen.

Marthin Luther merupakan tokoh reformasi gereja yang lahir di Jerman tahun 1483. Pada 31 Oktober 1517 Marthin Luther menyampaikan 95 dalil untuk memprotes ajaran Paus tentang surat penghapusan siksa. Dalam bidang pendidikan, Luther berkontribusi dalam pendidikan nonformal dengan mengembangkan katekismus untuk pendidikan orang awam dan para imam. ${ }^{41}$ Tokoh reformasi yang lainnya seperti Zwingli (1484-1531), John Calvin(1509-1564) di Swiss dan John Knox (1505-1572) di Skotlandia mereka juga mengadakan sekolah dan mengembanngkan katekismus untuk membantu pengajaran iman untuk anak-anak. Selanjutnya,ada Ignatius dari Loyola yang disebut pendidik jalan kehidupan suci yang lahir pada tahun 1491 di Spanyol utara. ${ }^{42}$ Ignatius menetapkan Jesuit sebagai sayap gereja dibidang pendidikan dan misi, dan menawarkan sejumlah pendidikan terbaik pada masa itu, dengan metode pendidikan yang telah teruji , tanpa memandang dari mana asal mereka. ${ }^{43}$ Comenius adalah salah satu pemimpin pendidikan pada masa itu, merupakan seorang uskup dan guru dari Moravia yang hidup 1592-1670 sering disebut bapak gerakan baru pendidikan. Ia menulis tentang praktik pendidikan yang baik, mengembangkan kurikulum dan berupaya menggunakan pendidikan untuk membentuk dan memberikan makan jiwa manusia dan menolongnya menemukan solusi bagi penyakit dunia. ${ }^{44}$

\section{Pendidikan Kristen Paska Reformasi Gereja}

Setelah Reformasi gereja 1517, gereja terus berkembang demikian juga dengan pendidikan agama Kristen. Robert Raikes (1735-1811) perintis sejarah dan

\footnotetext{
${ }^{39}$ Hardi Budiyana, Dasar-Dasar Pendidikan Agama Kristen (Solo: STT Berita Hidup Solo, 2011). 84-85

${ }^{40}$ Made Nopen Supriadi, "Filsafat Sebagai Ancilla Theologiae Dan Implementasinya Pada Masa Kini," SESAWI:Jurnal Teologi Dan Pendidikan Kristen 1, no. 1 (2019): 31-42.

${ }^{41}$ Michael J, Fondasi Pendidikan Abad 21. 24-25

${ }^{42}$ Budiyana, Dasar-Dasar Pendidikan Agama Kristen. 95

${ }^{43}$ Michael J, Fondasi Pendidikan Abad 21. 25

${ }^{4}$ Ibid.
} 
perkembangan sekolah minggu memulai sekolah minggu pada 1750, dan terus berkembang. Pendidikan yang awalnya hanya diberikan kepada anak-anak miskin untuk mengajarkan moral dan iman menjadi bagian lahan pendidikan bagi gereja. ${ }^{45}$ Mendekati abad kesembilan belas, ada gerakan yang berbeda yang menambah peningkatan pendidikan gereja. Gerakan misi yang terjadi ditahun 1800an mendorong pengembangan sekolah-sekolah Alkitab dan Institut-institut, pelatihan kepada orang dewasa untuk memberitakan Injil dan memuridkan orang lain dalam iman. Beberapa pemimpin gereja mulai menggunakan waktu luang mereka untuk mengajar moral dan agama, termasuk mengadakan kamp Kristen.

Awal abad kedua puluh atau tepatnya tahun 1903, sebuah konvensi diadakan di Chicago-Amerika Serikat dimana terbentuklah Religious Education Association dibawah kepemimpinan William Rainey Harper dan George Albert Coe. ${ }^{46}$ Konvesi ini mempromosikan pekerjaan pendidikan yang baik di gereja serta pendidikan agama di sekolah-sekolah umum. Vocation Bible School menjadi inovasi pelayanan kependidikan pada awal abad kedua puluh. Robert G. Boville meluncurkan gerakan VBS modern 1901 di New York City dan melibatkan mahasiswa perguruan tinggi untuk mengajar anak-anak untuk berpartisipasi dalam ibadah, pengajaran Alkitab, prakarya dan kegiatan yang bersifat rekreasi. ${ }^{47}$

E. Perkembangan Pendidikan Kristen di Indonesia

Sebelum masuk kepada relevansi pendidikan masa kini, ada baiknya terlebih dahulu melihat perkembangan pendidikan di Indonesia. Menurut penulis relevansi landasan historis pendidikan Kristen ini juga perlu melihat bagaimana perkembangan pendidikan di Indonesia terlebih pendidikan Kristen. Mendiskusikan relevansi pendidikan Kristen masa kini kurang lengkap jika tidak membahas pendidikan Kristen dalam konteks Indonesia. Menurut Sianipar, pembahasan pendidikan agama Kristen dalam pelaksanaanya tidak dapat berjalan sendiri namun harus ditopang secara nonformal dan inforlmal. ${ }^{48}$ Lebih lanjut Sianipar juga menjelaskan bahwa tujuan dari pendidikan agama Kristen adalah membangun karakter, akhlak peserta didik yang memungkinkan mereka untuk memberikan dampak positif bagi masyarakat luas. ${ }^{49}$

Tidak dapat dipungkiri bahwa pendidikan di Indonesia sangat dipengaruhi oleh pendidikan Portugis dan Belanda. Sebagaimana dalam catatan sejarah pendidikan zaman penjajah, tim penulis Kementerian Pendidikan dan kebudayaan menulis bahwa, sejarah pendidikan yang melaksanakan system pengajaran dengan wujud lembaga yang bernama sekolah sebenarnya sudah dimulai pada abad ke-16 yaitu ketika datangnya bangsa Portugis ke Indonesia. ${ }^{50}$ Kedatangan bangsa Portugis ini juga diikuti oleh bangsa Spanyol yang juga melakukan ekspansi. Dalam hal pendidikan, pemikiran Ignatius dari Layola juga ikut dibawa oleh para militer dari bangsa ini dalam melakukan ekspedisi ke Asia. Ordo Jesuit yang didirikan oleh Ignatius menghasilkan pengikut yang bernama Fransicus Xaverius yang memiliki pemikiran untuk mendirikan sekolah-sekolah terutama di wilayah non Kristen termasuk Indonesia. Wilayah Indonesia timur seperti Maluku dan Nusa Tenggara Timur menjadi basis penyebaran di Indonesia dan

\footnotetext{
${ }^{45}$ Budiyana, Dasar-Dasar Pendidikan Agama Kristen. 111-112

${ }^{46}$ Michael J, Fondasi Pendidikan Abad 21. 30

${ }^{47}$ Ibid. 31

${ }^{48}$ desi Sianipar, "Pendidikan Agama Kristen Yang Membebaskan: Suatu Kajian Historis Pak Di

Indonesia," Jurnal Shanan 1, no. 1 (March 1, 2017): 136-157.

${ }^{49}$ Ibid.

${ }^{50}$ Tim Penulis et al., "SEJARAH PENDIDIKAN DI INDONESIA ZAMAN PENJAJAHAN,"

KEMENDIKBUD (n.d.). 5
} 
pendidikan agama menjadi pelajaran yang penting bagi sekolah-sekolah katolik yang didirikan oleh ordo Jesuit.

Catatan sejarah melaporkan bahwa sekitar awal abad ke-17, giliran belanda yang masuk ke Indonesia. Belanda berhasil mengusir Portugis dari Indonesia, dan menguasai harta kekayaan orang-orang Portugis yang ada di Indonesia. Berkaitan dengan pendidikan orang Belanda hanya meneruskan apa yang sudah dilakukan oleh Portugis. Pendidikan diserahkan kepada gereja, diera penguasaan Belanda penekanan terhadap pelajaran agama masih menjadi prioritas. ${ }^{51}$ Selain itu juga pelajaran bahasa Belanda diperkenalkan sebagai pelajaran bahasa asing dengan buku pertamanya adalah $A B$ Boeck yang diterbitkan oleh VOC tahun 1611. Peranan bahasa asing Belanda sangat penting dalam sejarah pendidikan Indonesia. Namun memasuki abad ke-19, pendidikan lebih difokuskan kepada orang-orang keturunan eropa saja tidak bagi pribumi. Metode belajar juga telah diperkenalkan diantaranya metode membaca Prinsen dan Bouman. Buku-buku pelajaran juga mulai didatangkan dari Eropa untuk mendukung pendidikan di Hindia Belanda pada waktu itu. Singkatnya pengaruh pendidikan barat terutama Belanda sangat kuat bagi system pendidikan di Indonesia.

Demikian halnya dengan pendidikan agama Kristen. Seperti telah disinggung di atas pendidikan mula-mula yang dibawa oleh orang eropa ada pendidikan yang berpusat pada pengajaran agama atau pendidikan agama utamanya Kristen. Sekolah minggu juga didirikan oleh para awam yang bekerja di kantor dagang Belanda. Konsep sekolah minggu yang dibuka sama halnya dengan sekolah minggu di Inggris dan di Amerika. Dapat disimpulakn bahwa system dan pendidikan Kristen di Indonesia sangat dipengaruhi konsep pendidikan barat. Setelah kemerdekaan Indonesia terjadi konfrensi studi pendidikan agama di Sukabumi tahun $1955 .{ }^{52}$ Konfrensi ini diselenggarakan oleh panitia Theologi DGI dari 20 Mei sampai dengan 10 Juni 1955. Konfrensi yang dihadiri oleh Homrighousen ini sepakat untuk memperkuat pendidikan agama Kristen dengan mulai menyusun kurikulum pendidikan Kristen bersama yang melibatkan Dewan Gereja Indonesia.

\section{Relevansinya Dalam Pendidikan Kristen Masa Kini}

Pendidikan menjadi bagian dalam proses kehidupan manusia, proses untuk belajar, menjadi tahu dan bertumbuh. Melihat sejarah dan perkembangan pendidikan penting untuk belajar dari masa lalu bagaimana proses tantangan yang pernah terjadi sehingga tahu apa yang harus dilakukan dimasa depan. Landasan historis atau sejarah pendidikan agama Kristen, menolong untuk melihat relevansi pendidikan tersebut bagi pendidikan Kristen masa kini.

Uraian historis pada tulisan ini merupakan sebuah landasan bagi pendidikan Kristen yang dapat dilihat relevansinya bagi pendidikan Kristen masa kini. Dalam kajian ini, penulis memandang beberapa hal penting dari landasan historis ini bagi pendidikan Kristen masa kini. Beberapa pemikiran yang masih relevan tersebut dapat dituangkan sebagai berikut;

\section{Pendidikan Dalam Lingkungan Keluarga}

Dalam Perjanjian Lama, keluarga adalah lembaga pendidikan utama dalam masyarakat Yahudi. Dimana anak-anak dapat belajar secara informal dari orang tua mereka. Ayah mengajar, anak-anak tentang hukum Allah dan berdagang untuk mendapatkan nafkah. Menurut penulis, pendidikan dalam lingkungan keluarga masih

\footnotetext{
${ }^{51}$ Ibid. $11-12$

${ }^{52}$ https://ulepunyacerita.wordpress.com/2016/10/05/sejarah-pak-di-indonesia/., diakses 16 Juli
} 
relevan dalam pendidikan Kristen masa kini. Hingga saat ini, keluarga masih menjadi tempat yang ideal untuk mendidik, anak- anak. Pendidikan Kristen pada masa kini seharusnya tidak hanya terjadi pada ruang kelas gereja dan sekolah saja. Relevan dalam pandangan penulis tidak harus mencakup pada substansi yang terjadi pada era Perjanjian Lama, namun kepada metodenya. Penting pada masa kini untuk memulai pendidikan Kristen dalam keluarga, orang tua memiliki peran 70 persen bagi anak remaja untuk mengambil keputusan beriman kepada Yesus. Paradigma pendidikan Kristen yang terpenting adalah fondasi Alkitabiah, yang merupakan dasar pendidikan Kristen. ${ }^{53}$

\section{Mendidik Dengan Keteladanan}

Tentang pendidikan Kristen, pada masa Perjanjian Baru Yesus adalah central atau pusat pengajaran itu sendiri. Cara mengajar Yesus yang unik dan berotoritas dengan berbagai metode, mulai dari perumpamaan, bercerita dan dialog dan terlebih penting, Yesus menghidupi semua pengajarannya dengan keteladanan. Apa yang dilakukan Yesus yakni cara mengajar bahkan pengajaran-Nya, masih relevan dalam pendidikan Kristen masa kini. Seorang pendidik agama Kristen tidak hanya cukup pandai dalam mengusai materi tentang pendidikan Kristen atau Alkitab saja. Penting bagi pendidik atau pengajar pendidikan Kristen adalah memberikan teladan dari apa yang telah diajarkannya.

Tujuan dari pendidikan Kristen adalah mendorong orang untuk mendapatkan hubungan yang sungguh dengan Allah dan mengenal Kristus Yesus. ${ }^{54}$ Memperkenalkan jalan keselamatan di dalam Yesus melalui pendidikan Kristen dan menyampaikan karya Allah melalui materi pengajaran, menjadi salah satu cara untuk mendorong orang percaya memiliki hubungan yang sungguh dengan Allah. Dari masa-masa tujuan inti pendidikan Kristen tidak pernah berubah yaitu untuk mendorong orang mengenal Allah, memperbaiki moral, serta membangun iman. Barangkali yang berubah adalah metode dan model pembelajarannya saja.

\section{KESIMPULAN}

Setelah membuat kajian-kajian historis pendidikan Kristen dan melihat relevansi bagi pendidikan Kristen masa kini, maka dapat disimpulkan bahwa melihat kepada sejarah atau masalalu mengenai latar belakang dan perkembangan pendidikan Kristen itu perlu. Dengan melihat landasan sejarah akan membuat pendidik tahu bagaimana proses pendidikan Kristen dimulai dan juga tantangan yang pernah ada. Sehingga tahu apa yang harus dikerjakan dimasa sekarang ataupun masa depan ketika persoalan yang berkaitan dengan pendidikan Kristen itu ada.

Pendidikan Kristen tidak hanya dikhususkan disekolah formal saja seperti sekolah dasar, menengah ataupun perguruan tinggi. Keluarga dan gereja juga merupakan tempat pengajaran, tempat mendidik anak-anak dan orang-orang untuk mengenal Allah dan bertumbuh dalam iman. Sekolah minggu yang dimulai pada tahun 1750 oleh Robert Raikes menjadi tempat bagi gereja untuk mendidik orang dari segala usia untuk belajar firman Tuhan dan mengenal Allah. Para Reformator juga memperkuat pendidikan Kristen melalui katikesmus gereja sehingga pengajaran dapat

\footnotetext{
${ }^{53}$ Marde Christian Stenly Mawikere, "RESENSI: FONDASI PENDIDIKAN KRISTEN; SUATU PENGANTAR DALAM PERSPEKTIF INJILI," EDULEAD: Journal of Christian Education and Leadership 1, no. 1 (June 9, 2020): 108-113.

${ }^{54}$ G Riemer, Ajarlah Mereka; Kualitas Umat Kristiani Esok Ditentukan Oleh Pembinaan Kini (Jakarta: Yayasan Komunikasi Bina Kasih, 2006).
} 
dimaksimalkan. Oleh sebab itu,landasan historis atau sejarah pendidikan Kristen harus selalu diingat dan dipelajari untuk melihat relevansi dalam pendidikan Kristen masa kini sehingga dapat menolong dalam mengembangkan pendidikan Kristen itu sendiri. Sebagaimana pendidikan religius di era Perjanjian Lama, orang Yahudi memulai pendidikan melalui keluarga dan itu merupakan bagian dari sejarah pendidikan Kristen. Melihat landasan historis pendidikan Kristen, sangatlah relevan untuk tetap mengikuti model pendidikan Perjanjian Lama yakni memulai pendidikan spiritulitas Kristen dari keluarga.

\section{DAFTAR PUSTAKA}

Abineno, JL.CH. Sekitar Katekese Gerejawi. Jakarta: BPK Gunung Mulia, 2005.

Berkhof, Louis, and Cornelis Van Till. Foundation of Christian Education. Surabaya: Momentum, 2004.

Bilo, Dyulius Thomas. "Korelasi Landasan Teologis Dan Filosofis Dalam Pengembangan Prinsip Dan Praksis Pendidikan Agama Kristen." Phronesis Jurnal Teologi dan Misi 3, no. 1 (August 12, 2020): 1-22.

Boehlke, Robert R. Sejarah Perkembangan Pikiran \& Praktek Pendidikan Agama Kristen. Jakarta: BPK Gunung Mulia, 2018.

Budiyana, Hardi. Dasar-Dasar Pendidikan Agama Kristen. Solo: STT Berita Hidup Solo, 2011.

Creswell, John W. Research Design. 4th ed. Yogyakarta: Pustaka Pelajar, 2019.

den End, Th. Van. Harta Dalam Bejana. Jakarta: BPK Gunung Mulia, 2010.

Hamambira, Domianus Lodu. "Meletakan Kedudukan PAK Secara Tepat Dan Tepat Sasaran Seperti Ajaran Yesus.” Integritas: Jurnal Teologi 1, no. 1 (June 27, 2019): 74-92.

Mawikere, Marde Christian Stenly. "RESENSI: FONDASI PENDIDIKAN KRISTEN; SUATU PENGANTAR DALAM PERSPEKTIF INJILI." EDULEAD: Journal of Christian Education and Leadership 1, no. 1 (June 9, 2020): 108-113.

Michael J, Anthony. Fondasi Pendidikan Abad 21. Malang: Gandum Mas, 2017.

Pazmino, Robert W. Fondasi Pendidikan Kristen. Bandung: STT Bandung Dan BPK Gunung Mulia, 2012.

Penulis, Tim, Djohan Makmur, Pius Suryo Haryono, and Sukri Musa. "SEJARAH PENDIDIKAN DI INDONESIA ZAMAN PENJAJAHAN." KEMENDIKBUD (n.d.).

Riemer, G. Ajarlah Mereka; Kualitas Umat Kristiani Esok Ditentukan Oleh Pembinaan Kini. Jakarta: Yayasan Komunikasi Bina Kasih, 2006. 
Riniwati, Riniwati, Magdalena Magdalena, and Aprianty Susanty. "Implikasi Praktik Pendidikan Orang Yahudi Pasca Pembuangan Ke Babel Bagi Pendidikan Kristen Masa Kini." The Messengers: Jurnal Teologi Dan Pendidikan Kristen 1, no. 1 (2020): 25-38.

Sianipar, Desi. "PENDIDIKAN AGAMA KRISTEN YANG MEMBEBASKAN: SUATU KAJIAN HISTORIS PAK DI INDONESIA.” Jurnal Shanan 1, no. 1 (March 1, 2017): 136-157.

Supriadi, Made Nopen. "Filsafat Sebagai Ancilla Theologiae Dan Implementasinya Pada Masa Kini." SESAWI:Jurnal Teologi Dan Pendidikan Kristen 1, no. 1 (2019): 31-42.

Wijaya, Hengki. "METODE-METODE PENELITIAN DALAM PENULISAN JURNAL ILMIAH ELEKTRONIK.” In STRATEGI MENULIS JURNAL UNTUK ILMU TEOLOGI, 23-42. Semarang: Golden Gate Publishing, 2020.

SUMBER LAINNYA

https://ulepunyacerita.wordpress.com/2016/10/05/sejarah-pak-di-indonesia/ https://www.amazine.co/22032/sekolah-romawi-sistem-pendidikan-pada-jamanromawi-kuno/diakses 15 Juli 2020 